ISSN : 2623-2553 (Online)

ISSN : 2549-0532 (Cetak)

\title{
HUBUNGAN PENGETAHUAN TENTANG COVID-19 DENGAN KEPATUHAN PHYSICAL DISTANCING DI TARAKAN
}

\author{
Zulhafandi ${ }^{1}$, Ririn Ariyanti ${ }^{2}$, \\ ${ }^{12}$ Universitas Borneo Tarakan \\ Email: zulhafandi90@gmail.com \\ Dikirim : 31 Mei 2020 \\ Diterima : 10 Agustus 2020 \\ Diterbitkan : 3 September 2020
}

\begin{abstract}
Coronavirus 2019 (Covid-19) is a disease that is pandemic almost all over the world. Covid-19 infection can cause mild, moderate or severe symptoms. Covid-19 can be transmitted from humans through close contact and droplets, not through the air. WHO recommends physical distancing to prevent the spread of Covid-19. The purpose of this study was to relationship of knowledge about Covid-19 with obedience physical distancing. This research is a descriptive correlative study with cross sectional approach, the sampling technique used accidental sampling , the data is obtained from the Google form filled out by the researcher. The results of this study showed p-value 0,000< 0.05 so that there is a significant relationship between knowledge about Covid-19 with obedience physical distancing
\end{abstract}

Keywords: Knowledge, Covid-19, Physical Distancing 
Jurnal Kebidanan Mutiara Mahakam, Vol 8 , No 2, Tahun 2020, Hal 102-111

\section{PENDAHULUAN}

Pada tanggal 31 Desember 2019, dilaporkan pertama kali kasus Coronavirus diease 2019 (COVID-19) yaitu suatu penyakit yang sedang mewabah hampir diseluruh dunia. Kasus ini pertama kali ditemukan di Wuhan, provinsi Hubei Tiongkok yang melaporkan pertama kali mengenai kasis Pnemonia yang tidak diketahui penyebabnya (Prem et al., 2020). Data dari website WHO tanggal 9 Mei 2019 didapatkan kasus konfirmasi 4.024.973 dengan total kematian 279.321 orang. Sementara Indonesia didapatkan kasus konfirmasi 13.645 dengan total kematian 959 orang yang tersebar di seluruh Indonesia termasuk Kalimantan Utara dengan konfirmasi kasus 131 orang.

Infeksi COVID-19 dapat menimbulkan gejala ringan, sedang atau berat. Gejala klinis utama yang muncul yaitu demam $\left(\right.$ suhu $>38^{\circ} \mathrm{C}$ ), batuk dan kesulitan bernapas, selain itu dapat disertai dengan sesak memberat, fatigue, myalgia, gejala gastrointestinal seperti diare dan gejala saluran napas lain. Setengah dari pasien timbul sesak dalam satu minggu. Pada kasus berat perburukan secara cepat dan progresif seperti ARDS, syok septik, asidoses metabolic yang sulit dikoreksi dan perdarahan atau disfungsi kougalasi dalam beberapa hari. Pada beberapa pasien, gejala yang muncul ringan, bahkan tidak disertai dengan demam. Kebanyakan pasien memiliki prognosis baik dengan sebagian kecil kritis bahkan meninggal (Kemenkes RI, 2020a). Masa inkubasi COVID-19 rata-rata 5 sampai 6 hari dengan masa inkubasi terpanjang 14 hari, pada kasus COVID-19 yang berat dapat menyebabkan pneumonia, sindrom pernapasan akut, gagal ginjal dan bahkan kematian. Tanda dan gejala klinis yang di laporkan pada sebagian besar kasus adalah demam, dengan beberapa kasus mengalami kesulitan bernapas, dan hasil rontgen menunjukkan infiltrate pneumonia luas dikedua paru (Kemenkes RI, 2020b)

Beradasarkan bukti ilmiah, COVID-19 dapat menular dari manusia melalui kontak erat dan droplet, tidak melalui udara. Orang yang paling beresiko tertular penyakit ini adalah orang yang kontak erat dengan pasien COVID-19 termasuk yang merawat pasien COVID-19. Rekomendasi standar untuk mencegah penyebaran infeksi adalah melalui cuci tangan secara teratur, menerapkan etika batuk dan bersin, menghindari kontak secara langsung dengan ternak dan hewan liar serta menghindari kontak dekat dengan siapapun yang menunjukan gejala penyakit pernapasan seperti batuk dan bersin. Selain itu, menerapkan Pencegahan dan Pengendalian infeksi (PPI) saat berada di fasilitas kesehatan terutama unit gawat darurat (Kemenkes RI, 2020b)

Penyebaran Covid-19 dipengaruhi oleh aktivitas kegiatan manusia, termasuk banyaknya manusia dalam suatu ruangan atau suatu aktifitas (Kisser et al, 2020) 
Jurnal Kebidanan Mutiara Mahakam, Vol 8 , No 2, Tahun 2020, Hal 102-111

Penularan antar manusia di pengaruhi interaksi sosial yang dilakukan, penularan juga bervariasi tergantung dari usia dan lokasi melakukan kontak misalnya disekolah, kantor, dan dimasyarakat, Wuhan sebagai tempat bermulanya virus Covid-19 menerapkan physical distancing sebaga upaya non farmokologi untuk pencegah penularan Covid-19 (Prem et al., 2020). Physical distancing di rekomendasikan oleh pusat pengendalian dan pencegahan penyakit WHO untuk dilakukan yaitu dengan membatasi kegiatan publik baik itu diperusahaan maupun disekolah serta menetapkan jam malam, hal ini dilakukan untuk mencegah penyebaran Covid-19 (Pfattheicher et al, 2020). Physical distancing adalah menjaga jarak fisik untuk mencegah penyebaran virus corona yang dilakukan didalam maupun di luar rumah dengan jarak miniman 1 meter dengan orang lain (Kisser et al., 2020).

Tarakan merupakan satu-satunya Kota di provinsi Kalimantan Utara, Indonesia, memiliki luas wilayah $250.80 \mathrm{~km} 2$ serta merupakan kota terbesar di Kalimantan Utara sesuai dengan data kependudukan catatan sipil dan keluarga berencana, kota Tarakan berpenduduk 3.538 Jiwa, telah ditemukan kasus terkonfirmasi positif 35 orang dan meninggal dunia 0 orang. Tarakan tidak lepas dari pandemi Covid-19 bahkan untuk kota sekecil ini telah ditetapkan sebagai zona merah karena telah ada local trasnmision penyebaran Covid-19 (Tarakan.go.id).

Untuk meminimalisir korban, pemerintah telah menggalakkan berbagai upaya demi mencegah penyebaran virus ini, diantara upaya yang telah dilakukan adalah dengan mensosialisasikan social distancing yaitu pembatasan sosial yang selanjutnya diperketat lagi dengan physical distancing atau menjaga jarak fisik dari orang lain, yang membatasi interaksi sosial dan masyarakat. Himbauan mencuci tangan dengan sabun, hand sanitizer serta memakai masker untuk seluruh masyarakat pun juga sudah disosialisasikan. Bahkan sebelumnya pemerintah telah menghimbau kepada masyarakat untuk bekerja, sekolah, dan beribadah dirumah, namun hingga saat ini belum mampu memutus atau memperlambat penyebaran Covid 19 ini. Terakhir pemerintah juga telah menyetujui beberapa daerah di Indonesia termasuk Kota Tarakan untuk dilakukan kebijakan Pembatasan Sosial Berskala Besar (PSBB) yang memaksa aktivitas dan pergerakan masyarakat dibatasi secara ketat.

Oleh karena itu,dengan semakin bertambahnya kasus konfirmasi positif di Kota Tarakan (35 kasus positif), maka peneliti tertarik untuk melihat hubungan pengetahuan masyarakat tentang Covid-19 dengan kepatuhan dalam melakukan social distancing yang diharapkan penelitian ini dapat berguna bagi pemerintah dalam mengambil kebijakan 
Jurnal Kebidanan Mutiara Mahakam, Vol 8 , No 2, Tahun 2020, Hal 102-111

untuk mencegah penyebaran Covid-19 di Kota Tarakan.Pendahuluan menguraikan latar belakang/alasan mengapa dilakukan penelitian itu, diakhiri dengan masalah penelitian atau tujuan penelitian, dan jika perlu hipotesis.

\section{METODE PENELITIAN}

Jenis penelitian yang digunakan adalah deskriptif korelatif dengan desain cross sectional. Deskriptif korelatif merupakan sebuah penelitian yang ditujukan untuk mengetahui hubungan suatu variabel dengan variabel-variabel lain. Sedangkan cross sectional merupakan desain penelitian yang pengumpulan datanya dilakukan pada satu titik waktu atau at one point in time (Dahlan, 2014).

Tempat penelitian ini berlokasi di Kota Tarakan. Penelitian ini dimulai sejak AprilMei 2020. Populasi dalam penelitian ini adalah seluruh masyarakat yang tinggal di kota Tarakan. Dalam penelitian ini menggunakan non random sampling (non probability), metode pengambilan sampel dilakukan dengan metode accidental sampling yaitu pengambilan sampel berdasarkan kebetulan yaitu responden yang secara kebetulan mengisi google formulir yang disebarkan oleh peneliti pada bulan Maret-April 2020, serta memenuhi kriteria yang ditentukan oleh peneliti, yaitu bisa membaca, memiliki handpone serta bersedia menjadi responden serta kriteria exklusi nya yaitu tidak bersedia menjadi responden serta tidak bisa membaca.

Pengumpulan data pada penelitian ini dengan menggunakan kuisioner berupa pertanyaan tertutup yang terdiri dari bagian A mengenai karakteristik responden, bagian B adalah Kuisoner Pengetahuan. Dimana peneliti menyebarakan kuisioner kepada masyarakat Tarakan tanpa memperhatikan gender, pendidikan dan pekerkerjaan responden. Variabel pada penelitian ini adalah pengetahuan tentang covid-19 . dan kepatuhan dalam melakukan physical distancing.

Dalam penelitian ini peneliti menggunakan pertanyaan tertutup hal ini didasarkan pada pengetahuan responden berbeda beda dan dengan menggunakan skala guttman untuk mendapatkan jawaban yang tegas dan konsisten tentang permasalahan yang ditanyakan. Pada penelitian ini terjadi kemungkinan bias pada sampel selection karena peneliti menggunakan non probability accidental sampling, dikhawatirkan sampel yang dipilih tidak mewakili populasi warga tarakan. Usaha yang dilakukan peneliti untuk mengurangi bias adalah penyebaran kuisioner pada kelompok masyarakat yang lebih luas bukan hanya pada golongan tertentu saja. 
Jurnal Kebidanan Mutiara Mahakam, Vol 8 , No 2, Tahun 2020, Hal 102-111

Setelah data terkumpul pada google formulir maka peneliti melakukan coding, untuk menyusun data mentah secara sitematis (yang terdapat didalam kuisioner). Kemudian peneliti memindahkan data yang telah di ubah menjadi kode kedalam mesin pengolah data dalam hal ini peneliti menggunakan SPSS, setelah itu peneliti melakukan cleaning data untuk memastikan bahwa data yang dimasukkan kedalam SPSS sudah benar. Kemudian peneliti melakukan analisa data baik secara univariat untuk melihat distribusi frekuensi karakteristik responden dan variable univariat dan disajikan dalam bentuk table distribusi frekuensi. Setelah itu peneliti melakukan analisa data bivariat dimana peneliti menggunkan chisquare untuk menguji hipotesis antara variable independen dan dependen apakah ada hubungan atau tidak dengan cara membandingkan p-value dengan alfa, dimana alfa yang ditetapkan pada penelitian ini adalah 0,05 Uji Chisquere.

\section{HASIL DAN PEMBAHASAN}

Berdasarkan hasil penelitian yang telah dilakukan maka diperoleh karakteristik responden sebagai berikut

Tabel 1. Karaketeristik Responden Berdasarkan Umur

\begin{tabular}{lllll}
\hline Variabel & Mean & Median & SD & Min - Max \\
\hline Umur & 20,59 & 20,00 & 3,797 & $17-45$ \\
\hline
\end{tabular}

Dari tabel 1 diatas terdapat rata-rata responden yang mengisi kuisioner ini berusia 20 tahun, dengan usia responden termuda yaitu 17 tahun dan yang paling tua berusia 45 tahun.

Tabel 2. Tabel Distibusi Frekuensi Karakteristik Responden

\begin{tabular}{lll}
\hline Variabel & F & $\%$ \\
\hline $\begin{array}{lll}\text { Jenis Kelamin } \\
\text { Perempuan }\end{array}$ & 191 & 88,0 \\
Laki-laki & 26 & 12,0 \\
\hline Pendidikan & & \\
Dasar & 4 & 1,8 \\
Menengah & 193 & 88,9 \\
Tinggi & 20 & 9,2 \\
\hline Kecamatan & & \\
Tarakan Barat & 48 & 22,1 \\
Tarakan Timur & 103 & 47,5 \\
Tarakan Tengah & 39 & 18,0 \\
Tarakan Utara & 27 & 12,4 \\
\hline
\end{tabular}


Jurnal Kebidanan Mutiara Mahakam, Vol 8 , No 2, Tahun 2020, Hal 102-111

\begin{tabular}{lll}
\hline $\begin{array}{lll}\text { Status Pekerjaan } \\
\text { Tidak bekerja }\end{array}$ & 196 & 90,3 \\
Bekerja & 21 & 9,7 \\
\hline Kondisi saat ini & & \\
Tidak Khawatir & 1 & 0,4 \\
Cukup Khawatir & 187 & 86,2 \\
Sangat Khawatir & 29 & 13,4 \\
\hline
\end{tabular}

Berdasarkan hasil penelitian diperoleh bahwa mayoritas responden berjenis kelamin perempuan yaitu sebanyak 191 responden (88,0\%), mayoritas responden adalah pendidikan menengah yaitu 193 responden $(88,9 \%)$, mayoritas responden berasal dari Tarakan Timur yaitu 103 responden (47,5\%), mayoritas responden tidak bekerja yaitu 196 responden (90,3\%). Dan mayoritas responden cukup khawatir dengan kondisi penyebaran Covid-19 saat ini yaitu 187 responden $(86,2 \%)$.

Tabel 3 : Analisa Univariat

\begin{tabular}{lll}
\hline Variabel & $\mathrm{F}$ & $\%$ \\
\hline Tingkat Pengetahuan tentang & & \\
Covid-19 & & \\
Kurang & 1 & 0,5 \\
Cukup & 11 & 5,1 \\
Baik & 205 & 94,4 \\
\hline Phisical Distancing & & \\
Tidak Melakukan & 2 & 0,9 \\
Melakukan & 215 & 99,1 \\
\hline Total & 217 & 100 \\
\hline
\end{tabular}

Berdasarkan hasil penelitian pada tabel 3 diperoleh bahwa mayoritas responden memiliki tingkat pengetahuan baik yaitu 205 responden $(94,4 \%)$ dan mayoritas melakukan physical distancing yaitu 215 responden $(99,1 \%)$.

Tabel 4 Hubungan pengetahuan tentang Covid-19 dengan physical distancing

\begin{tabular}{ccccc}
\hline Variabel & \multicolumn{2}{c}{ Physical Distancing } & Total & P-Value \\
\cline { 1 - 3 } Pengetahuan & $\begin{array}{c}\text { Tidak } \\
\text { melakukan }\end{array}$ & melakukan & & \\
\hline kurang & 1 & 0 & 1 & 0,000 \\
Cukup & 0 & 11 & 11 & \\
Baik & 1 & 204 & 205 & \\
Total & 2 & 215 & 217 & \\
\hline
\end{tabular}


Jurnal Kebidanan Mutiara Mahakam, Vol 8 , No 2, Tahun 2020, Hal 102-111

Hasil Uji statistic chi squre dengan menggunakan bantuan SPSS diperoleh nilai ( $p$ value) 0,00 nilai $p$-value lebih kecil dari $\alpha$ 0,05 menunjukkan ada hubungan yang significant antara tingkat pengetahuan tentang Covid-19 dengan kepatuhan melakukan physical distancing di kota Tarakan.

Menurut Notoadmojo (2010), sebelum orang mengadopsi perilaku baru didalam diri orang tersebut terjadi proses sebagai berikut kesadaran (awareness) dimana orang tersebut menyadari dalam arti mengetahui terlebih dahulu terhadap stimulasi (objek), Merasa (interest) tertarik terhadap stimulasi atau objek tersebut, menimbang-nimbang (evaluation) terhadap baik dan tidaknya stimulasi terhadap dirinya, mencoba (trial) dimana subjek mulai mencoba melakukan sesuai dengan apa yang dikehendaki dan adaption dimana subjek berprilaku sesuai dengan pengetahuan, kesadaran dan stimulasi.

Mayoritas responden pada penelitian ini adalah memiliki jenjang pendidikan menengah yaitu 193 responden (88,9\%), selain itu informasi tentang Covid-19 diberitakan pada media cetak, elekteronik maupun media sosial sehingga memudahkan masyarakat dalam mengakses informasi mengenai Covid-19 sehingga responden mayoritas memliki tingkat pengetahuan yang baik yaitu 205 responden (94,4\%). Pengetahuan dipengaruhi oleh beberapa faktor yaitu faktor pendidikan yang merupakan suatu usaha untuk mengembangkan kepribadian dan kemampuan didalam dan diluar sekolah baik formal maupun non formal dan berlangsung seumur hidup disebutkan bahwa makin tinggi pendidikan seseorang maka semakin mudah orang tersebut menerima informasi, faktor infomasi/media masa dengan berkembangnya teknologi akan menyediakan bermacam-maca media massa yang dapat mempengaruhi pengetahuan masyarakat tentang informasi terbaru, sehingga saran komunikasi seperti televisi, radio, surat kabar, majalah dan lain lain mempunyai pengaruh besar terhadap penyampaian opini dan kepercayaan sesorang.

Menurut Notoadmojo, (2010) Pengetahun juga dipengaruhi oleh faktor pekerjaan dimana seseorang yang bekerja disektor formal memiliki akses yang lebih baik terhadap informasi termasuk informasi kesehatan, faktor sosial, budaya dan ekonomi dimana kebiasaan dan tradisi seseorang tidak melalui suatu penalaran tetapi bersifat rutinitas, mayoritas responden pada penelitian tidak bekerja yaitu 196 responden (90,3\%) namun responden dapat mendapatkan informasi mengenai Covid-19 bermacam-macam media massa yang setiap senantiasa memberikan informasi mengenai penyebaran dan pencegahan Covid-19 Status ekonomi seseorang juga menentukan tersedianya suatu fasilitas yang diperlukan untuk kegiatan tertentu sehingga status sosoal ekonomi akan 
Jurnal Kebidanan Mutiara Mahakam, Vol 8 , No 2, Tahun 2020, Hal 102-111

mempengaruhi pengetahuan seseorang, faktor lingkungan dimana merupakan segala sesuatu yang ada disekitar individu, baik fisik, biologis maupun sosial, lingkungan berpengaruh terhadap proses masuknya pengetahuan kedalam individu yang berada dala lingkungan tersebut hal ini dikarenakan adanya interaksi timbal balik dalam lingkungan, mayoritas responden cukup khawatir dengan kondisi penyebaran Covid-19 saat ini yaitu 187 responden $(86,2 \%)$ sehingga responden patuh dalam melakukan physical distancing.

Faktor usia dimana usia mempengaruhi daya tangkap dan pola piker seseorang, semakin bertambah usia maka akan semakin berkembang pula daya tangkap dan pola pikirnya sehingga pengetahuan yang diperoleh semakin baik, usia rata rata responden yang mengisi kuisioner ini berusia 20 tahun, dengan usia responden termuda yaitu 17 tahun dan yang paling tua berusia 45 tahun (Notoadmojo, 2010). Tingkat Pengetahuan yang baik ini juga tercermin pada kepatuhan responden dalam melakukan sosial distancing dimana dari 205 responden yang memiliki tingkat pengetahuan baik 204 melakukan physical distancing. Hal ini menunjukan bahwa semakin baik pengetahuan responden mengenai Covid-19 maka responden akan melakukan physical distancing untuk mencegah penyebaran Covid-19. Hal ini sejalan dengan penelitian Prem dimana dia mengungkapkan bahwa penularan antar manusia di pengaruhi dengan siapa dia berinteraksi, penularan juga bervariasi tergantung dari usia dan lokasi melakukan kontak misalnya disekolah, kantor, dan dimasyarkat, Wuhan sebagai tempat bermulanya virus Covid-19 menerapkan physical distancing sebaga upaya non farmokologi untuk pencegah penularan Covid-19 (Prem et al., 2020) seperti yang kita ketahui bersama bahwa Wuhan sudah dapat mengatasi pandemic ini dengan melakukan physical distancing.

Selain physical distancing untuk mencegah penyebaran Covid 19 perlu juga dilakukan isolasi mandiri sehingga ini dapat mencegah penyebaran Covid-19 hingga $60 \%$ Karena dengan melakukan pembatasan hubungan pisik dengan orang lain akan mengurangi orang yang terpapar Covid-19 dan hal ini tentu saja di pengaruhi oleh pengetahuan dan kesadaran dari setiap orang untuk melakukan physical distancing (Kucharski et al., 2020). Virus corona diketahui penyebaran utamanya melalui tetesan pernapasan, terutama saat orang yang terinfeksi batuk atau bersin. Oleh karena itu, menjaga jarak fisik yang aman dianjurkan untuk mengurangi penularan. Phisical distancing di rekomendasikan oleh pusat pengendalian dan pencegahan penyakit WHO untuk dilakukan yaitu dengan membatasi kegiatan publik baik itu diperusahaan maupun disekolah serta menetapkan jam malam, hal ini dilakukan untuk mencegah penyebaran Covid-19 (Kisser et al., 2020). 
WHO telah merekomendasikan menjaga jarak lebih dari 1 meter dari orang lain. Sementara, beberapa pakar kesehatan menyarankan untuk menjaga jarak setidaknya dua meter dari orang lain. Sejumlah langkah dapat diambil untuk meningkatkan ruang fisik antara orang-orang, termasuk tinggal di rumah lebih banyak, bekerja dari rumah jika mungkin, membatasi tamu di rumah, menghindari pertemuan besar dan transportasi umum. jarak fisik diperlukan untuk melindungi kondisi fisik semua orang, tetapi kesehatan mental juga penting (Galea, Merchant, \& Lurie, 2020).

Meskipun secara statistik ada hubungan, tetapi penelitian ini adalah jenis penelitian kuantitatif dimana hasil yang didapatkan tergantung dari jawaban responden terhadap instrumen yang diberikan, oleh karena itu tidak dapat melihat secara mendalam tentang pengetahuan pasien, selain itu metode pengambilan sampel non probability accidental sampling, yang peneliti gunakan merupakan kelemahan dari penelitian ini.

\section{SIMPULAN}

Berdasarkan hasil penelitian ini menunjukan nilai $p$-value lebih kecil dari $\alpha 0,05$ dapat disimpulkan bahwa pengetahuan tentang covid19 berhubungan dengan kepatuhan physical distancing pada subyek di kota Tarakan Kalimantan Utara.

Penelitian ini menyarankan perlunya penelitian dengan subyek yang lebih besar serta menggunakan tehnik sampling secara random sampling.

\section{DAFTAR PUSTAKA}

Ardan, M., Rahman, F. F., \& Geroda, G. B. (2020). The Influence Of Physical Distance To Student Anxiety On Covid-19, INDONESIA. Journal of Critical Reviews, 7(17), 1126-1132.

Dahlan, S. (2014). Statistik untuk kedokteran dan kesehatan Deskritif, Bivariat, dan Multivariat dilengkapi aplikasi menggunakan SPSS (6th ed.). Jakarta: Epidemiologi Indonesia.

Galea, S., Merchant, R., \& Lurie, N. (2020). TheMental Health Consequences ofCOVID19 and Physical Distancing The Need for Prevention and Early Intervention Opinion. Jama Internal Medicine, 28(8), 666-675. https://doi.org/10.1002/da.20838

Kemenkes RI. (2020a). Pedoman Bagi Ibu Hamil, Ibu Nifas, dan Bayi Baru Lahir selama Social Distancing. Jakarta: Kementrian Kesehatan Republik Indonesia.

Kemenkes RI. (2020b). Pedoman Pencegahan dan Pengendalian Coronavirus Disease (COVID-19). Jakarta: Kementrian Kesehatan Republik Indonesia.

Kisser, S., Tedijanto, C., Lipsitch, M., \& Grad, Y. H. (2020). Social Distancing Strategis For Curbing the COVID-19 Epidemic. MedXriv, (1). 
Jurnal Kebidanan Mutiara Mahakam, Vol 8 , No 2, Tahun 2020, Hal 102-111

Kucharski, A. J., Klepac, P., Conlan, A., Kissler, S. M., Tang, M., Fry, H., ... Edmunds, J. (2020). Effectiveness of isolation, testing, contact tracing and physical distancing on reducing transmission of SARS-CoV-2 in different settings. MedRxiv, 2020.04.23.20077024. https://doi.org/10.1101/2020.04.23.20077024

Notoadmojo, S. (2010). Ilmu Prilaku Kesehatan. Jakarta: Rineka Cipta.

Pfattheicher, S., Nockur, L., Böhm, R., Sassenrath, C., \& Petersen, M. B. (2020). The emotional path to action: Empathy promotes physical distancing during the COVID19 pandemic. PsyArXiv [working paper]. https://doi.org/10.31234/OSF.IO/Y2CG5

Prem, K., Liu, Y., Russell, T. W., Kucharski, A. J., Eggo, R. M., Davies, N., ... Hellewell, J. (2020). The effect of control strategies to reduce social mixing on outcomes of the COVID-19 epidemic in Wuhan, China: a modelling study. The Lancet Public Health, 2667(20), 1-10. https://doi.org/10.1016/s24682667(20)30073-6 